\title{
PROPERTIES OF A NEW FUNGAL $\beta$-GALACTOSIDASE WITH POTENTIAL APPLICATION IN THE DAIRY INDUSTRY
}

\section{Rubens Cruz*; Vinícius D’Arcádia Cruz; Juliana Gisele Belote; Marcelo de Oliveira Khenayfes; Claudia Dorta; Luiza Helena dos Santos Oliveira}

Departamento de Ciências Biológicas, Faculdade de Ciências e Letras, Universidade Estadual de São Paulo, UNESP, Assis, SP, Brasil

Submitted: January 07, 1999; Returned to authors for corrections: April 09, 1999; Approved: July 30, 1999

\begin{abstract}
$\beta$-Galactosidase or $\beta$-D-galactoside-galactohydrolase (EC. 3.2.1.23) is an important enzyme industrially used for the hydrolysis of lactose from milk and milk whey for several applications. Lately, the importance of this enzyme was enhanced by its galactosyltransferase activity, which is responsible for the synthesis of transgalactosylated oligosaccharides (TOS) that act as functional foods, with several beneficial effects on consumers. Penicillium simplicissimum, a strain isolated from soil, when grown in semisolid medium showed good productivity of $\beta$-galactosidase with galactosyltransferase activity. The optimum $\mathrm{pH}$ for hydrolysis was in the 4.0-4.6 range and the optimum $\mathrm{pH}$ for galactosyltransferase activity was in the 6.0-7.0 range. The optimum temperature for hydrolysis and transferase activity was $55-60^{\circ} \mathrm{C}$ and $50^{\circ} \mathrm{C}$, respectively, and the enzyme showed high thermostability for the hydrolytic activity. The enzyme showed a potential for several industrial applications such as removal of $67 \%$ of the lactose from milk and $84 \%$ of the lactose from milk whey when incubated at their original $\mathrm{pH}(4.5$ and 6.34 , respectively) under optimum temperature conditions. When incubated with a $40 \%$ lactose solution in $150 \mathrm{mM} \mathrm{McIlvaine} \mathrm{buffer,} \mathrm{pH} 4.5$, at $55^{\circ} \mathrm{C}$ the enzyme converted $86.5 \%$ of the lactose to its component monosaccharides. When incubated with a $60 \%$ lactose solution in the same buffer but at $\mathrm{pH} 6.5$ and $50^{\circ} \mathrm{C}$, the enzyme can synthetize up to $30.5 \%$ TOS, with $39.5 \%$ lactose and $30 \%$ monosaccharides remaining in the preparation.
\end{abstract}

Key words: $\beta$-Galactosidase, galactosyltransferase, galactooligosaccharides, lactose, prebiotic effect

\section{INTRODUCTION}

$\beta$-galactosidase or $\beta$-D-galactosidegalactohydrolase (EC. 3.2.1.23) is used industrially to obtain the hydrolyzates of lactose from milk and milk whey for utilization in bakery products, ice creams, animal feed and as a sugar source for several fermentation products (23). Furthermore, economic aspects of transport and storage require the concentration of milk whey by evaporation or ultrafiltration. The easy crystallization of lactose, however, represents a strong limitation in such

\footnotetext{
* Corresponding author. Mailing Address: Departamento de Ciências Biológicas, Faculdade de Ciências e Letras - UNESP, Campus de Assis. Av. Dom Antônio, 2.100, CEP 19800-000, Assis, SP, Brasil. E-mail: rcruz@femanet.com.br Telefax: (+5518) 322-2933 R. 296
} 
processes. Monosaccharides derived from hydrolysis are highly soluble and usually prevent the crystallization of the remaining lactose (23). Enzymatic hydrolysis of lactose from milk and milk whey is also desirable for lactose-intolerant individuals (10).

Enzymologists have recently attributed great importance to the galactosyltransferase activity of $\beta$-galactosidases to obtain the synthesis of oligosaccharides with 2 or more galactose units starting from lactose. Solutions with high lactose concentrations, such as evaporated milk whey, submitted to the action of $\beta$-galactosidase from some microorganisms suffer a transgalactosylation reaction, producing a galactooligosaccharide mixture or transgalactosylated oligosaccharides (TOS) which act as functional foods, with several beneficial effects for their consumers. Diets enriched with TOS significantly increase the population of Bifidobacterium, Lactobacillus and some species of Streptococcus, with a consequent decrease in the concentration of putrefactive bacteria in the gut of humans and other animals (prebiotic properties). This change in the intestinal flora (bifido effect) composition has been proposed to be responsible for the decrease of putrefactive products in the feces, for a lower blood cholesterol content $(1,13)$, higher $\mathrm{Ca}^{2+}$ absorption, a smaller loss of bone tissue in ovariectomized rats (2), and a lower incidence of colon cancer (21). Besides, TOS are non-cariogenic sugars and can be widely used as additives in several infant formulations, and in the manufacture of candy, pastry, bread and jams because of their heat stability (17).

This work describes the hydrolytic and transgalactosylase activities of a semi-purified $\beta$-galactosidase produced by a strain of Penicillium simplicissimum isolated from soil. The enzyme was applied to milk, milk whey and to a highly concentrated lactose solution, showing several desirable properties for industrial application.

\section{MATERIALS AND METHODS}

Enzyme. $\beta$-galactosidase from Penicillium simplicissimum was produced by semi-solid fermentation, semi-purified by precipitations with $\left(\mathrm{NH}_{4}\right)_{2} \mathrm{SO}_{4}$ and cold acetone followed by exchange chromatography on DEAE-Sephadex A-50 and
CM-cellulose columns. These procedure allowed to obtain a fraction with $27.66 \mathrm{U} / \mathrm{mg}$ of protein and a purification of 9.7 times (3).

Enzyme assay. The hydrolytic activity of $\beta$-galactosidase was determined using two substrates, i.e. $O$-nitrophenyl- $\beta$-D-galactopyranoside (ONPG) and lactose. In the first case, properly diluted aliquots of $0.1 \mathrm{ml}$ of enzyme solution were incubated with $1.0 \mathrm{ml}$ of $2.0 \mathrm{mM}$ ONPG solution in $75 \mathrm{mM}$ McIlvaine buffer, $\mathrm{pH} 5.0$, at $50^{\circ} \mathrm{C}$. After $5 \mathrm{~min}$ the reaction was stopped by the addition of $3.0 \mathrm{ml}$ of $0.1 \mathrm{M} \mathrm{NaOH}$ and the $O$-nitrophenol (ONP) liberated was estimated at $420 \mathrm{~nm}$ with a Pharmacia spectrophotometer (Molar Absorptivity = $\left.5,200 \mathrm{~cm}^{-1} \cdot \mathrm{M}^{-1}\right)$. When lactose was utilized as substrate, the reaction medium consisted of $1.0 \mathrm{ml}$ of appropriately diluted enzyme solution and $2.0 \mathrm{ml}$ of $3.0 \%$ lactose solution in $75 \mathrm{mM}$ Mcllvaine buffer, $\mathrm{pH} 5.0$, at $50^{\circ} \mathrm{C}$. After $30 \mathrm{~min}$ the reaction was stopped by deproteinization with $0.1 \mathrm{ml}$ of $0.33 \mathrm{~N} \mathrm{Ba}(\mathrm{OH})_{2}$ plus $0.1 \mathrm{ml}$ of $5.0 \%(\mathrm{w}: \mathrm{v}) \mathrm{ZnSO}_{4}$, followed by centrifugation at $1,600 \mathrm{xg}$ for $10 \mathrm{~min}$. The released glucose was determined by the glucose-oxidase method, as cited by Cruz et al (4). In both cases an enzyme unit $(U)$ was defined as the amount of enzyme necessary to liberate $1 \mu \mathrm{mol}$ of the products per min under the assay conditions. Protein content was determined by the method of Lowry et al (16), and bovine serum albumin was utilized as standard.

Effect of pH and temperature on hydrolytic activity. The $\mathrm{pH}$ effect of the purified enzyme on the hydrolysis of both substrates, was estimated after incubation of the reaction systems in $75 \mathrm{mM}$ McIlvaine buffer in the 2.6 to $7.6 \mathrm{pH}$ range, at $50^{\circ} \mathrm{C}$. The optimum temperature for ONPG and lactose was determined in the 35 to $70^{\circ} \mathrm{C}$ range in $75 \mathrm{mM}$ McIlvaine buffer, $\mathrm{pH}$ 5.0. Heat denaturation whitout the presence of substrates was studied by treating the enzyme samples in the same buffer and at the same molarity at $55^{\circ}, 60^{\circ}, 65^{\circ}$ and $70^{\circ} \mathrm{C}$ for $2 \mathrm{~h}$. Aliquots of $0.2 \mathrm{ml}$ of each treatment were removed every 5 minutes, cooled immediately in an ice bath and kept at $4{ }^{\circ} \mathrm{C}$ for $24 \mathrm{~h}$ before the determination of residual activity using ONPG as substrate.

Optimal pH and temperature for galactosyltransferase action. To study the effects of $\mathrm{pH}$ and temperature on galactosyltransferase action it was utilized reaction systems consisting of $50 \mathrm{ml}$ of $20 \%$ (w:v) lactose solution in $75 \mathrm{mM}$ McIlvaine buffer and $18 \mathrm{U}$ of hydrolytic activity of the enzyme. Optimum $\mathrm{pH}$ was determined in the 3.0 to 7.6 range 
at $45^{\circ} \mathrm{C}$ and optimum temperature in the $40^{\circ}$ to $60^{\circ} \mathrm{C}$ range, at $\mathrm{pH}$ 6.5. The reactions were stopped after $8 \mathrm{~h}$ by treatment with boiling water for $5 \mathrm{~min}$ and the reaction products were analyzed by high performance liquid chromatography (HPLC).

Preparation and enzymatic treatment of milk and milk whey. Milk was prepared by rehydration of $100 \mathrm{~g}$ of defatted powdered milk in distilled water at the 1:10 ratio (w:v). The fractions to be used for milk whey production were supplemented with $2 \mathrm{~N} \mathrm{HCl}$ until the $\mathrm{pH}$ dropped to 4.5 , for isoelectric precipitation of their proteins. After centrifugation at $1,600 \mathrm{x}$ for $5 \mathrm{~min}$, the total sugar content of $50 \mathrm{ml}$ aliquots of the milk and milk whey thus obtained were adjusted to $5.1 \%$ (w:v) according to the method of Dubois et al. (6), and the samples were incubated with $10.2 \mathrm{U}$ at their original $\mathrm{pH}(6.34$ and 4.5, respectively), at $50^{\circ} \mathrm{C}$ for $12 \mathrm{~h}$. Samples were removed at predetermined time intervals, the reactions were stopped by treatment with boiling water for $5 \mathrm{~min}$ and the sugars were analyzed by HPLC.

Hydrolysis of highly concentrated lactose solutions. To verify the hydrolytic action of the enzyme on concentrated solutions, $100 \mathrm{ml}$ of a $40 \%$ (w:v) lactose solution in $150 \mathrm{mM}$ McIlvaine buffer, $\mathrm{pH} 4.5$, was incubated with $100 \mathrm{U}$ of $\beta$-galactosidase at $50^{\circ} \mathrm{C}$. Samples of $2.0 \mathrm{ml}$ were collected every $6 \mathrm{~h}$ and the reaction was stopped by deproteinization with the $\mathrm{Ba}(\mathrm{OH})_{2}-\mathrm{ZnSO}_{4}$ system as described above. The sugars in the reaction medium were quantified by HPLC.

TOS production. A $50 \mathrm{ml}$ aliquot of the reaction medium was prepared with $26.6 \mathrm{U}$ of $\beta$-galactosidase and lactose solution in $150 \mathrm{mM}$ McIlvaine buffer, $\mathrm{pH}$ 6.5 , at a final concentration of $60 \%(\mathrm{w}: \mathrm{v})$, which was the maximal lactose concentration permitting total solubilization in that medium. The reaction system was maintained at $50^{\circ} \mathrm{C}$ and $2 \mathrm{ml}$ samples were removed at predetermined time intervals for sugar analysis by HPLC.

Carbohydrate analysis. The carbohydrates in the reaction medium were analyzed with a Shimadzu LC-10A chromatography apparatus, model RID 6-A, equipped with a refraction index detector and a 250 x $4.6 \mathrm{~mm}$ Supelcosil $\mathrm{LC}-\mathrm{NH}_{2}$ column in a room at $20^{\circ} \mathrm{C}$. A system consisting of acetonitrile-water (4:1) was used as solvent and the flow rate was $2.0 \mathrm{ml} \cdot \mathrm{min}^{-1}$. Glucose, galactose, lactose, (Merck) and the galactooligosaccharides raffinose and stachyose (Sigma) were used as standards. Calculations were performed using the external standardization techniques. All experiments were conducted in triplicate and the relative standard deviation was less than $5 \%$.

\section{RESULTS AND DISCUSSION}

Effect of pH. As shown in Fig. 1, the enzyme acted in a similar way on both substrates tested, but showed a broader range of optimum $\mathrm{pH}$ for the hydrolysis of lactose. Its maximum activity in $\mathrm{pH} 4.0$ to 4.6 coincided with the behavior of other fungal $\beta$-galactosidases such as those produced by $A$. oryzae (20) A. niger (9), Alternaria alternata (14) and Sterigmatomyces elviae (19). Fig. 1 also shows that, under the assay conditions used, the optimum $\mathrm{pH}$ for galactosyltransferase action was in the neutral range, with a peak at $\mathrm{pH} 6.5$, in contrast to the hydrolytic activity which peaked within the acid range. Higher transferase action at higher $\mathrm{pH}$ than the optimum $\mathrm{pH}$

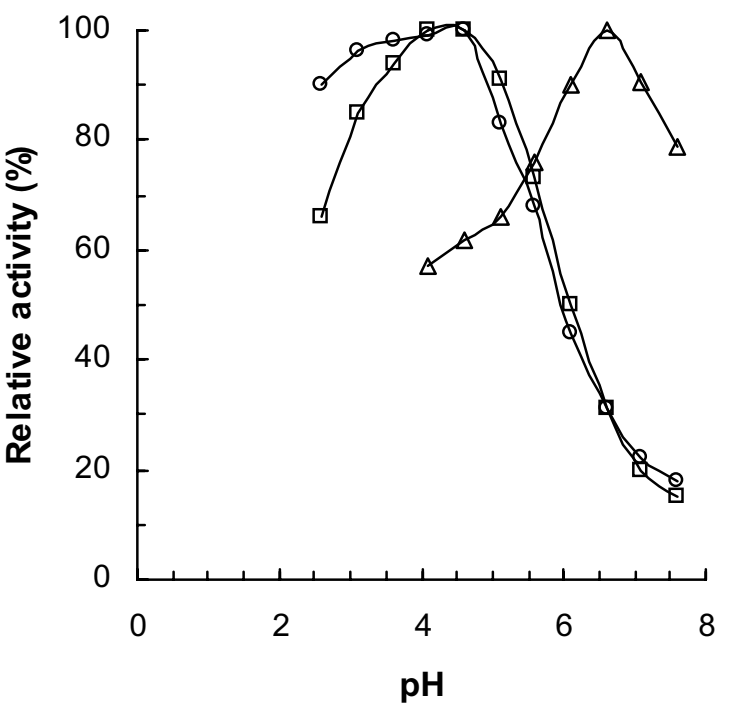

Figure $1-\mathrm{pH}$ effect on hydrolysis of lactose (o), ONPG ( $\square$ ) and galactosyltransferase activity $(\Delta)$ of $\beta$-galactosidase from Penicillium simplicissimum.

for hydrolytic activity has been previously described by Kikushi and Ishiwata (14), using $\beta$-galactosidase from Alternaria alternate and by Cruz et al (5) using fructosyltransferase from Aspergillus japonicus for fructooligosaccharides (FOS) synthesis from concentrated solutions of sucrose. According to authors, these findings may be explained by inhibition 
of transferase activity by the high monosaccharides concentrations (specially glucose) in the reaction medium at optimum hydrolytic $\mathrm{pH}$.

Effect of temperature. As shown in Fig. 2, $\beta$-galactosidase from Penicillium simplicissimum showed higher activity on lactose at temperatures below $60^{\circ} \mathrm{C}$ and lower activity at temperatures above 55 and $60^{\circ} \mathrm{C}$ compared to its action on ONPG. These differences may be possibly explained by thermal denaturation, since the enzyme was exposed to these temperatures for a longer time ( 30 minutes) when lactose was used as substrate, as opposed to only 5 min when ONPG was used as substrate. Fig. 3 shows that hydrolytic activity of the enzyme was reduced by only $14 \%$ during exposure to $60^{\circ} \mathrm{C}$ for $120 \mathrm{~min}$. It is also possible that the transferase activity of the enzyme is more sensitive to heat than the hydrolytic activity, a fact that would explain the maximum galactosyltransferase activity observed at

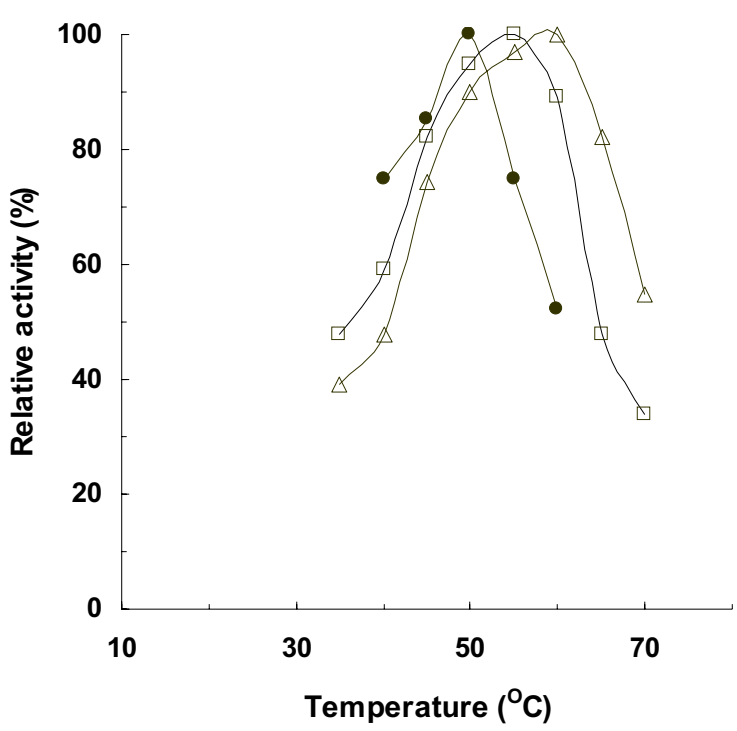

Figure 2 - Temperature effect on hydrolysis of lactose ( $\square$ ), ONPG $(\Delta)$ and galactosyltransferase ( $\bullet$ ) activity of the enzyme.

$50^{\circ} \mathrm{C}$ (Fig. 2). In any case, the thermostability of $\beta$-galactosidase from Penicillium simplicissimum is higher than that of the enzymes produced by $A$. niger (9), A orizae (20), Alternaria alternata (14) and some yeasts (19) already proposed for milk lactose removal and/or TOS synthesis. Thermostable enzymes are desirable in industrial processes because they can accelerate the reactions and prevent microbial contamination (8).

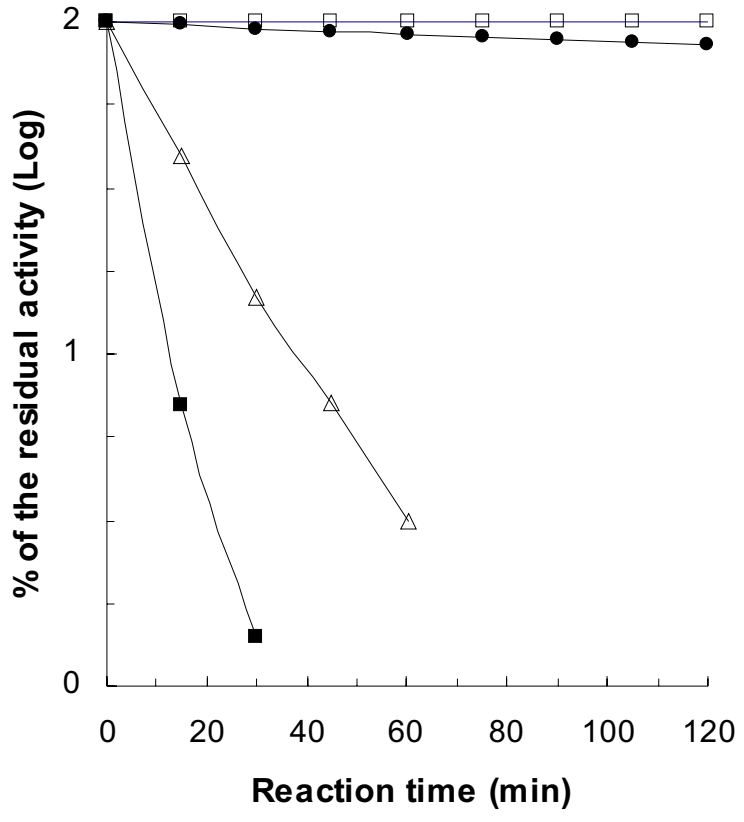

Figura 3 - Thermal denaturation of $\beta$-galactosidase from Penicillium simplicissimum. $\left(\square 55^{\circ} \mathrm{C} ; \bullet 60^{\circ} \mathrm{C} ; \Delta 65^{\circ} \mathrm{C} ; 70^{\circ} \mathrm{C}\right)$

Lactose removal from milk and milk whey. As shown in Fig. 4, after $10 \mathrm{~h}$ of the proposed treatment only $33 \%$ and $16 \%$ lactose remained in milk and in milk whey, respectively. The higher efficiency of the enzyme in the hydrolysis of milk whey compared to milk lactose is explained by the differences in $\mathrm{pH}$ between the tests, i.e., $\mathrm{pH} 4.5$ for whey and $\mathrm{pH} 6.34$ for milk lactose. Despite the reduced hydrolytic activity shown by the enzyme at $\mathrm{pH}$ above 6.0 , under the assay conditions (Fig. 1) the rate of milk lactose hydrolysis $(67 \%)$ can be considered highly satisfactory. According to Gikas and Lopes-Leiva review (8), some traditional enzymatic processes for milk lactose removal available on the market present a final hydrolytic value of 50 to $70 \%$ at reaction times longer than $18 \mathrm{~h}$. The high rate of lactose hydrolysis obtained here perhaps may be explained by the high $\mathrm{Ca}^{2+}$ content of milk. It should be pointed out that, under the present assay conditions, divalent cations stimulated the performance of the enzyme, while chelating agents (EDTA, for example) inhibited the action of the enzyme (3).

In the enzymatic treatment of milk and milk whey the higher TOS synthesis was verified at $3 \mathrm{~h}$ of reaction. However it is difficult to explain the smaller TOS production in milk treatment that in milk whey treatment, especially because its reaction was 


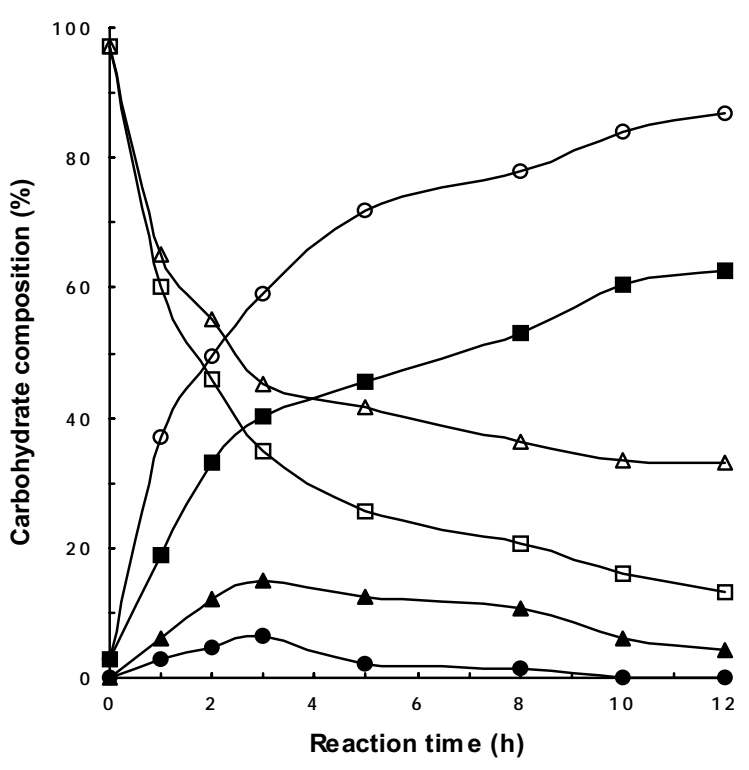

Figure 4 - Hiydolysis of lactose from milk and milk whey by $\beta$-galactosidase from Penicillium simplicissimum. (M - milk; MW - milk whey) $-\Delta \mathrm{M}$ lactose; $\square \mathrm{MW}$ lactose; $\mathrm{M}$ monosacch.; o MW monosacch; $\triangle$ M TOS; • MW TOS.

performed at higher pH. Fig. 4 also shows that TOS synthetized in the milk treatment decreases quickly after the $3 \mathrm{~h}$ of reaction, simultaneously with the monosaccharides increase. This could suggest that the same higher content of $\mathrm{Ca}^{+2}$ that stimulates the hydrolitic activity, inhibits the transferase activity. Besides, could the highest protein content in milk reduce the galactosyltransferase activity? Unfortunately the specialized literature has not discussed those questions. No change in milk protein solubility was observed during the course of the experiment, suggesting the absence of proteases in the enzymatic mixture used.

Hydrolysis of highly concentrated lactose solutions. As shown in Table 1, highly concentrated lactose solutions such as those present in milk whey concentrates can be hydrolyzed by $\beta$-galactosidase from Penicillium simplicissimum as long as the enzyme is applied to the solution at high enzyme:substrate ratios and under conditions of optimum $\mathrm{pH}$ and temperature. Under these conditions, when $100 \mathrm{U}$ of $\beta$-galactosidase was added to $100 \mathrm{ml}$ of a $40 \%$ lactose solution the reaction was timedependent up to $24 \mathrm{~h}$, when the residual lactose content dropped to only $13.5 \%$, with $83 \%$ monosaccharides being obtained. When the reaction time reached $48 \mathrm{~h}$ the process reached equilibrium with a production of
Table 1 - Hydrolysis of lactose by $\beta$-galactosidase from Penicillium simplicissimum.

\begin{tabular}{rccc}
\hline $\begin{array}{c}\text { Time } \\
(\mathrm{h})\end{array}$ & $\begin{array}{c}\text { Galac }+ \text { Gluc } \\
(\%)\end{array}$ & $\begin{array}{c}\text { Residual lactose } \\
(\%)\end{array}$ & $\begin{array}{c}\text { TOS* } \\
(\%)\end{array}$ \\
\hline 6 & 77.2 & 17.2 & 5.6 \\
12 & 81.7 & 13.8 & 4.5 \\
24 & 86.0 & 13.5 & 0.5 \\
36 & 79.1 & 16.5 & 4.4 \\
48 & 76.2 & 19.5 & 4.3 \\
60 & 77.2 & 17.4 & 5.4 \\
72 & 77.8 & 17.4 & 4.8 \\
\hline
\end{tabular}

Lactose $40 \%$; $\mathrm{pH} 4.5$; Temperature $50^{\circ} \mathrm{C}$; Enzyme/Substrate ratio $=2.5 \mathrm{U} / \mathrm{g}$

* Transgalactosylated oligosaccharides

about $77 \%$ monosaccharides, $17.5 \%$ residual lactose and the rest as TOS. The increase of the remaining lactose from 13.5 to $17.4 \%$ in the interval time between 24 and $48 \mathrm{~h}$ is inside of admitted variation coefficient. However it could also be explained by the phenomenon of the lactose re-synthesis, suggesting that in high concentration, glucose can also act as acceptor molecule of galactose.

Industrially, the concentration of milk whey is an extremely desirable process because of the economy in the cost of storage and transport processes, which are limited by the easy crystallization of lactose. Thus, the enzymatic hydrolysis of lactose in these concentrates also represents a suitable process since its constituent monosaccharides are highly soluble and prevent the crystallization of the remaining lactose.

TOS production. As shown in Fig. 5, the maximum percentage of TOS obtained was $30.5 \%$, reached at the $16 \mathrm{~h}$ of reaction, with $39.5 \%$ of remaining lactose and $30 \%$ of monosaccharides, mainly glucose. Among the TOS, only tri- and tetrasaccharides were synthesized and longer chain oligosaccharides were not found at any time during the course of the reaction. This observation confirms the results described by Smart et al. (22), according to which high lactose concentrations favor the synthesis of short- chain oligosaccharides. It was also observed that complete inhibition of oligosaccharide synthesis occurred when the monosaccharides content of the reaction medium reached the total concentration of TOS. From this reaction time (16 h) on, oligosaccharide hydrolysis, rather than synthesis, occurred, which was more marked than lactose hydrolysis. This was also observed for the lowest 


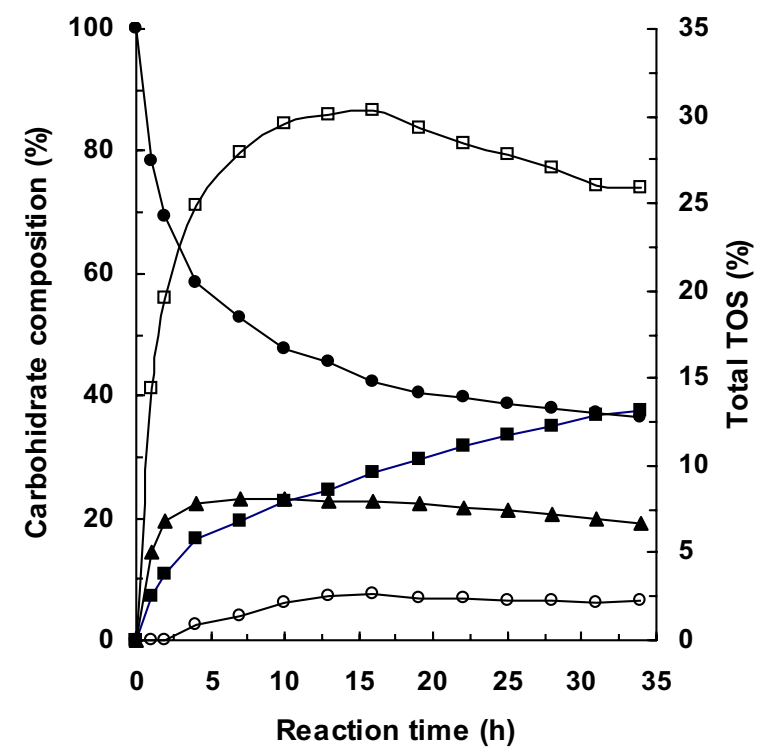

Figure 5 - Reaction course for transgalactosylated oligassacharides (TOS) synthesis in the best conditions of $\mathrm{pH}$ (6.5), temperature $\left(50^{\circ} \mathrm{C}\right)$ and lactose concentration $(60 \% \mathrm{w}: \mathrm{v})-$ - lactose, monosacchides, $\mathbf{\Delta}$ trissacharides; O tetrassacharides; $\square$ total TOS.

lactose concentrations tested, which presented a lower rate of lactose conversion to TOS.

The maximal percentage of lactose conversion $(30.5 \%)$ to TOS obtained in this work can be considered quite satisfactory when compared to the values reported by others. "Oligomate 50", a trade mark registered for a product marketed in Japan, contains $50 \%$ to $52 \%$ TOS (17). However, this product is obtained by two successive enzymatic treatments, with a consequent increase in cost. The values reported here are slightly higher than those reported by Dumortier et al (7) - 29\% conversion working with $\beta$-galactosidase from a strain of Bifidobacterium bifidum and with an initial lactose content of $60 \%$. The value obtained here corresponds to an oligosaccharide content of $183 \mathrm{mg} / \mathrm{ml}$ and is $60 \%$ higher than the $114 \mathrm{mg} / \mathrm{ml}$ value obtained with $\beta$-galactosidase from Aspergillus oryzae by Iwasaki et al. (11). It is also much higher than the content of $80.7 \mathrm{mg} / \mathrm{ml}, 111.5 \mathrm{mg} / \mathrm{ml}$ and $81.5 \mathrm{mg} / \mathrm{ml}$ obtained by $\mathrm{Ji}$ et al. (12) with $\beta$-galactosidases from Aspergillus oryzae, Kluyveromyces fragilis, and a mixture of both, respectively.

The prebiotic properties of several oligosaccharides have been demonstrated with the administration of reduced amounts of the products to animals $(13,15,18)$. Thus, it is possible that the product obtained here, with $183 \mathrm{mg} / \mathrm{ml}$ or $30.5 \%$ of TOS, is quite acceptable for use in the formulation of diets with a prebiotic effect. Furthermore, according to Matsumoto et al. (17), it is possible to separate the oligosaccharides from the residual lactose and glucose using cation-exchange resins, thus obtaining a final product with $85-99 \%$ TOS. Studies on this topic are currently underway in our laboratory.

\section{ACKNOWLEDGEMENTS}

This work was supported by grants from Fundação de Amparo à Pesquisa do Estado de São Paulo (FAPESP) e Fundação para o Desenvolvimento da UNESP (FUNDUNESP).

\section{RESUMO}

\section{Propriedades de uma nova $\boldsymbol{\beta}$-galactosidade fúngica com potencialidade para emprego na indústria de latícinios}

A $\beta$-galactosidase ou $\beta$-D-galactosídeogalactohidrolase (EC. 3.2.1.23) é uma importante enzima utilizada industrialmente na hidrólise da lactose do leite e soro de leite para diversas aplicações. Ultimamente, sua importância foi realçada por sua atividade de galactosiltransferase responsável pela síntese de oligossacárides transgalactosilados (TOS) que atuam como alimentos funcionais, trazendo diversos efeitos benéficos para seus consumidores. Penicillium simplicissimum, uma linhagem isolada do solo, mostrou grande produtividade de $\beta$-galactosidase com atividade de galactosiltransferase quando crescida em meio semi-sólido. Seu pH ótimo para hidrólise está na faixa de 4,0-4,6 e para a atividade de galactosiltransferase na faixa de 6,0-7,0. A temperatura ótima para hidrólise e transferase foram encontradas a $55-60^{\circ} \mathrm{C}$ e $50^{\circ} \mathrm{C}$, respectivamente e a enzima mostrou maior termoestabilidade para a atividade de hidrolase. A enzima mostrou potencialidade para diversas aplicações industriais como a remoção de $67 \%$ da lactose do leite e $84 \%$ da lactose do soro de leite quando incubada nos respectivos pHs oroginais $(4,5$ e 6,34 , respectivamente) em condições ideais de temperatura. Quando incubada com uma solução a 40\% em tampão 
de McIlvaine $150 \mathrm{mM}, \mathrm{pH} 4,5$ a $55^{\circ} \mathrm{C}$ a enzima converteu $86,5 \%$ da lactose em seus monossacarídeos componentes. Quando aplicada a uma solução com $60 \%$ de lactose no mesmo tampão mas em $\mathrm{pH} 6,5 \mathrm{e}$ $50^{\circ} \mathrm{C}$, a enzima pode sintetizar até $30,5 \%$ de TOS, deixando $39,5 \%$ de lactose residual e $30 \%$ de monossacárides.

Palavras-chave: $\beta$-galactosidase, galactosiltransferase, galactooligossacárides, lactose, efeito prebiótico

\section{REFERENCES}

1. Chonan, O; Matsumoto, K.; Watanuki, M. Effect of galactooligosaccharides on calcium absorption and preventing bone loss in ovariotomized rats. Biosc. Biotech. Biochem. 59(2): 236-39, 1995.

2. Chonan, O.; Watanuki, M. Effect of galactooligosaccharides on calcium absorption in rats. J. Nut. Sci. Vitamin. 41(1): 95-104, 1995.

3. Cruz, R. O emprego da $\beta$-galactosidase de Penicillium simplicissimum na obtenção de soro de leite rico em oligossacárides transgalactosilados (TOS). Assis, SP, 1998, 148 p. (Pos-Doctoral Thesis. Faculdade de Ciências e Letras. UNESP).

4. Cruz, R.; Baptistela, J.C.; Wosiacki, G. Microbial $\alpha$-galactosidase for soymilk processing. J. Food Sci. 46(4): 1196-200, 1981.

5. Cruz, R.; Cruz, V.D.; Belini, M.Z.; Belote, J.G.; Vieira, C. R. Production of fructooligosaccharides by mycelia of Aspergillus japonicus immobilized in calcium alginate. Biores. Technol. 65: 139-143, 1998.

6. Dubois, M.; Gilles, K.A.; Hamilton, J.K.; Riber, B.A.; Smith, H. Colorimetric method for determination of sugars and related substances. Anal. Chem. 28: 350-56, 1956.

7. Dumortier, V.; Brassart, C.; Bouquelet, S. Purification and properties of a $\beta$-D-galactosidase from Bifidobacterium bifidum exhibiting a transgalactosylation reaction. Biotech. Appl. Biochem. 19(3): 341-354, 1994.

8. Gikas, V.; Lopez-Leiva, M. Hydrolysis of lactose: a literature review. Food Sci. Rev. 20 (1): 2-12., 1985.

9. Greenberg, N.A.; Mahoney, R.R. (1981). Rapid purification of $\beta$-galactosidase (Aspergillus niger) from a commercial source. J. Food Sci. 46(3): 684-87.

10. 10-Honkanen, R.; Pulkkinen, P.; Jarvinen, R.; Kroger, H.; Lindstedt, K.; Tuppurainen, M.; Uusitupa, M. Does lactose intolerance predispose to low bone density? A population-based study of perimenopausal Finnish women. Bone (New York), 19(1): 23-28, 1996.
11. Iwasaki, K.; Nakajima, M.; Nakao, S. Galactooligosaccharides production from lactose by an enzyme batch reaction using B-galactosidase. Proc. Biochem. 31(1): 69-76, 1995.

12. Ji, W.M.; Kyeong, T.; Su, W.L.; Jai, Y.L. A study on the galactooligosaccharides produced from transgalactosylation with $\beta$-galactosidase of Aspergillus and Kluyveromyces. Kor. J. Food Sci. Technol. 27(3): 271-280, 1995.

13. Kikuchi, H.; Andrieux, C.; Riototti, M.; Bensaada, M.; Popot, F.; Beaumatin, P.; Szylit, O. Effect of two levels of transgalactosylated oligosaccharide intake in rats associated with human microflora on bacterial glycolytic activity, end products of fermentation and bacterial steroid transformation. J. Appl. Bacteriol. 80(4): 439-446, 1996.

14. Kikuchi, T.; Ishiwata, N. Purification and characteristics of $\beta$-galactosidase from Alternaria alternata. J. Jap. Soc. Food Sci. Technol. 25: 1023-1029, 1993.

15. Korpela, R.; Teuri, T. Effect of a galacto-oligosaccharidecontaining yoghurt on constipation in the elderly. Symposium "Non-digestible oligosaccharides: healthy food for the colon?", Wageningen, The Netherlands. 1997, p. 157.

16. Lowry, G.H.; Rosenbrouk, N.J.; Farr, A.L.; Randal, R.J. Proteins measurement with the Folin phenol reagent. J. Biol. Chem. 193: 265-71, 1951.

17. Matsumoto, K.; Kobayashi, Y.; Uuima, S.; Watanabe, T.; Tanaka, R.; Kan, T.; Akio, K.; Sumihara, S. Galactooligosaccharides. In: Nakakuki, T. ed. Oligosaccharides: production, properties and applications. Gordon and Breach Science Publishers, Shizuoka, Japan., 1995, p. 90-106.

18. Mul, A.J. Application of oligosaccharides in animal feeds. International Symposium "Non-digestible oligosaccharides: healthy food for the colon?", Wageningen, The Netherlands, 1997, p. 106.

19. Onishi, N.; Tanaka, T. Purification and properties of a novel thermostable galactooligosaccharide-producing $\beta$-galactosidase from Sterigmatomyces elviae CBS8119. Appl. Environ. Microbiol. 61(11): 4026-4030, 1995.

20. 20- Park, Y.K.; De Santi, M.S.S.; Pastore, G.M. Production and characterization of $\beta$-galactosidase from Aspergillus oryzae. J. Food Sci. 44(1): 100-103, 1979.

21. Rowland, I.R. Influence of non-digestible oligosaccharides on gut functions related to cancer colon. International Symposium. "Non-digestible oligosaccharides: healthy food for the colon?", Wageningen, The Netherlands 1997, p. 100.

22. Smart, J.B. Transferase reactions of $\beta$-galactosidase from Streptococcus thermophilus. App. Microbiol. Biotechnol. 34(4): 495-501, 1991.

23. Yang, S.T; Silva, E.M. Novel products and new technologies for use of a familial carbohydrate, milk lactose. J. Dairy Sci. 78(11): 2541-2562, 1995. 